SHS Web of Conferences 10, 00011 (2014)

DOI: $10.1051 /$ shsconf/20141000011

C Owned by the authors, published by EDP Sciences, 2014

\title{
Relations of social care home residents as a precondition for coping with loneliness
}

\author{
V. Gudzinskiene \\ Mykolas Romeris University, Lithuania
}

\begin{abstract}
The article analyses relations of social care home residents with relatives, former neighbours and members of local community. The focus is laid on residents' feeling of loneliness as one of the outcomes of unsuccessful adaptation. The emphasis is also laid on the fact that this feeling may occur when an individual is strongly related neither with other residents of social care homes nor with relatives. The analysis of correlations revealed that statistically relevant correlations exist between visits of relatives and possession of children and relatives. The residents of Utena Social Care Home with children pointed out that they are visited statistically significantly. The article discusses communication among residents of social care home and their participation in the community activity.
\end{abstract}

\section{Introduction}

People, who start living in the social care homes, undergo dramatic changes. This is related not only with change of living place but also with living under a new daily regime, relations with the social care home staff, other residents, alienation from their family, former neighbours, decrease in personal space. Elderly people have to adapt to new living conditions. The process of adaptation to a radically different environment is complicated for elderly people and is a long lasting process, where social workers play a very important role. Behaviour and competences of social workers determine success of elderly people's adaptation process.

A feeling of loneliness is one of the consequences of unsuccessful adaptation. This feeling may occur when an individual is not strongly linked with residents of social care home or with own relatives. Efforts of social workers during the adaptation period may be not efficient namely due to individual's selfisolation, absence of social relations; therefore, the research aimed to identify if social links condition both successful adaptation in the social care home and assistance of social workers.

The problems of elderly people were analysed by a big number of Lithuanian scientists: J. Pivorienè (2003, 2004, 2008) analysed the influence of family, relatives and friends on elderly lonely people; D. Staniulevičienè (2004), V. Gudžinskienė, D. Mačiuikienė (2011) described activity of elderly people and their living style; S. Koskinen, R. Naujaniené, N. Večkienė (2004), N. Večkienè, V. Večkys, M. Vidugirytė - Hartblay (2004) and others conducted researches on ageing in the community. The problem of ageing has been topical not only in Lithuania. Foreign researchers: G.W. Allport (1998), P. Baltes and M. Baltes (1990, 1993), G. Becker (1994), M. Ferry, R. Baker, (2006), J.E. Birren (1996),

This is an Open Access article distributed under the terms of the Creative Commons Attribution License 4.0, which permits unrestricted use, distribution, and reproduction in any medium, provided the original work is properly cited. 


\section{SHS Web of Conferences}

C.S. Kart (1997) and others analysed psychological and social peculiarities and problems of elderly people in other countries.

The goal of the research: to identify links of social care home residents with relatives and other residents of social care home.

The research methods: analysis of scientific pedagogical, psychological, social and sociological literature and legal documents; quantitative research; correlation analysis; comparison, generalisation.

The research methodology. The quantitative methodology was applied in the research. The questionnaire survey was designed to reveal the researched problem. The research was conducted employing principle of targeted sampling from January to March, 2011. The survey was carried out using the method of questionnaire survey to research residents of Utena Social Care Home, which was selected purposefully. The respondents were surveyed face-to-face. Such method was chosen due to particularity of the target group (it may be too difficult for elderly people to fill in questionnaires). The data analysis was conducted applying SPSS 14.0 programme, using Chi-square criterion at significance level of 0.05 and T-test criterion at significance level of 0.05 .

The analysis also contains the averages with z-values. Computing of the averages leads to the average scores, which do not reveal if the averages statistically significantly correlate. Therefore, the primary scores are standardised and converted into z-values. The average of all the evaluations is equalled to 0 , and primary scores are transformed into values within the range from -3 to 3 . The values that are lower than -1 and higher than +1 refer to statistically significant average deviation.

The balance of the Likert scale is also calculated in the survey: the difference between the comparative part of negative and positive answers in percent. The balance may acquire values ranging from -100 , when all the respondents chose the most negative variant of the response, to +100 , when all the participants in the survey point to the most positive variant of the response. If the number of negative and positive is equal, the balance meaning is equal to 0 . If the value of balance is -10 , it means that the number of negative values exceeded the number of positive values by 10 percent.

The data analysis presents only data on statistically significant differences.

The sample. The research employed targeted sampling. The research aimed to investigate all the residents of Utena Social care home, whose health condition was appropriate for answering to the questionnaire questions. Over a hundred of residents (105) out of 290 elderly people living in the social care home participated in the research. The maximum error of survey results is $7.7 \%$ with reliability of $95 \%$.

The Utena Social Care Home was purposefully selected for the survey due to compliance of its activity with the researched problem.

\section{The research results}

According to empiric data of the research on the residents of Utena social care home, the majority of the residents are visited by relatives $(86 \%)$ and $14 \%$ of the respondents pointed out that nobody visits them (see: Fig. 1).

Relatives visit the residents most frequently (69\%), slightly fewer respondents, who are visited, mentioned children (42\%) and one out of nine respondents pointed out that they are visited by neighbours (11\%). Furthermore, the residents pointed out that they are visited by friends, grandchildren or wife (see: Fig. 2).

Thus, the majority $(86 \%)$ of the residents in the Utena social care home do not break links with the society outside the institution: they are visited by relatives, children, even by neighbours or friends. However, $14 \%$ of the respondents do not maintain any relations with relatives, friends or neighbours. They make up the most vulnerable group.

The correlation analysis revealed that the statistically significant relations exist between visits of relatives and possession of children, relatives. The residents of Utena social care home, who have 
Int. Conf. SOCIETY. HEALTH. WELFARE.

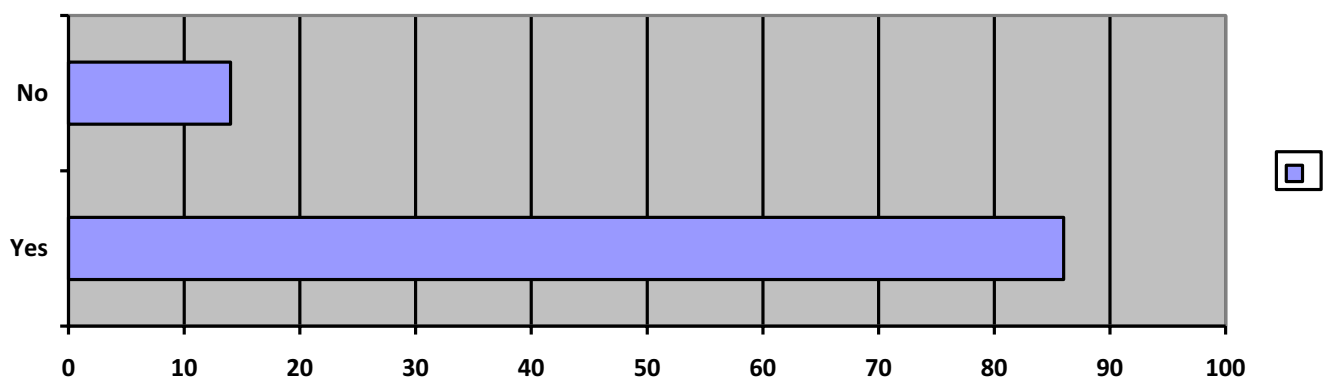

Figure 1. Visits by relatives (percentage).

\section{If you are visited, point out who by:}

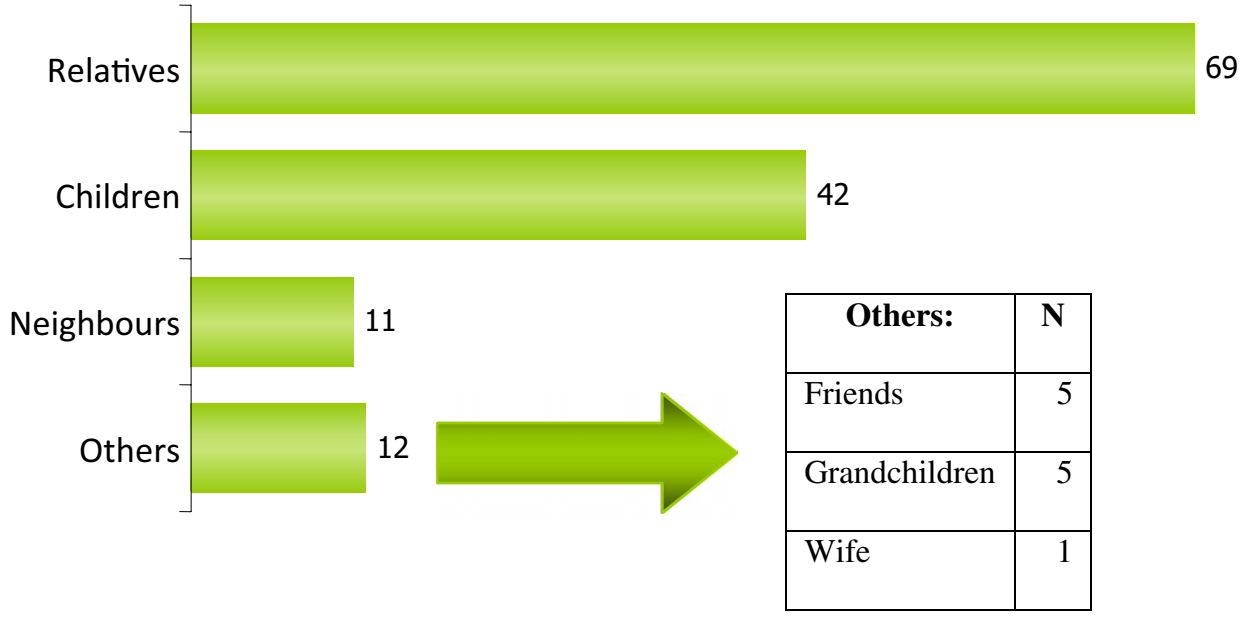

Figure 2. Who visit residents of Utena social care home (percentage).

children or relatives, statistically significantly more frequently pointed out that the latter visit them ( $95 \%$ and $88 \%$ respectively). It is interesting to notice that not all the residents, who have children, are visited by them; however, relatives visit almost all the residents. It is natural that the residents, who have children, are more frequently visited by them (62\%). The social status also condition who visit the respondents: widowed mentioned more frequently that their children visit them (59\%) and single residents are more frequently visited by relatives $(83 \%)$.

The questions regarding communication among residents of the social care home and their involvement in the activity of community showed if the above-mentioned $14 \%$ of the respondents in Utena social care home are really lonely and do not communicate with anybody. The research data revealed that two thirds $(69 \%)$ of the respondents maintain close relations with other residents of the social care home and comparatively big proportion of them $(29 \%)$ communicate with them only occasionally and the absolute majority $(2 \%)$ stated that they do not maintain any relations with other residents of the social care home (see: Fig. 3).

The same proportion of the residents of Utena social care home (72\%), who state that they maintain close relations with other residents, feel full-fledged members of the social care home. The Chi-square criterion revealed that the respondents, who communicate with other residents of the care institution, more frequently stated that they feel full-fledged members of the community. The ones, who did not 
Do you maintain close relations with other residents of the social care home?

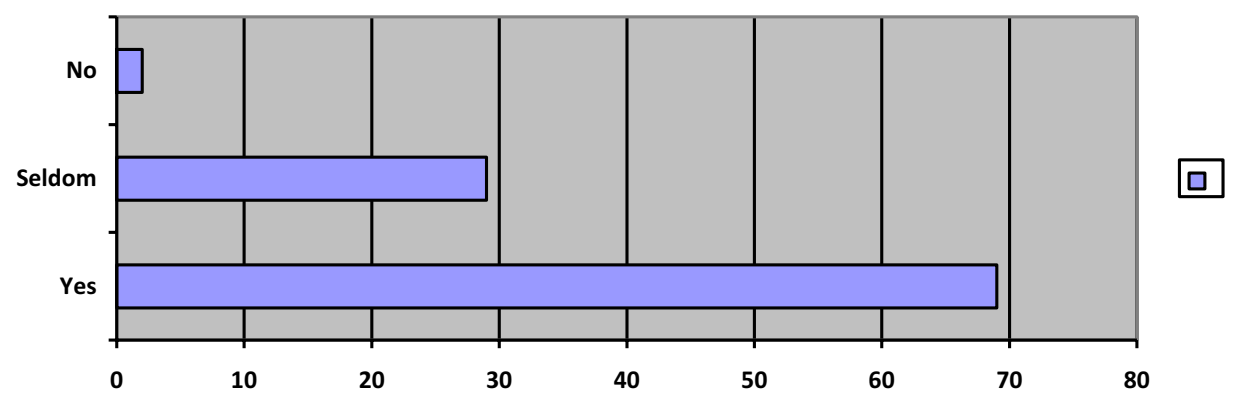

Figure 3. Maintenance of close relations with other residents of the social care home (percentage).

\section{Do you feel a full-fledged member of the social care home?}

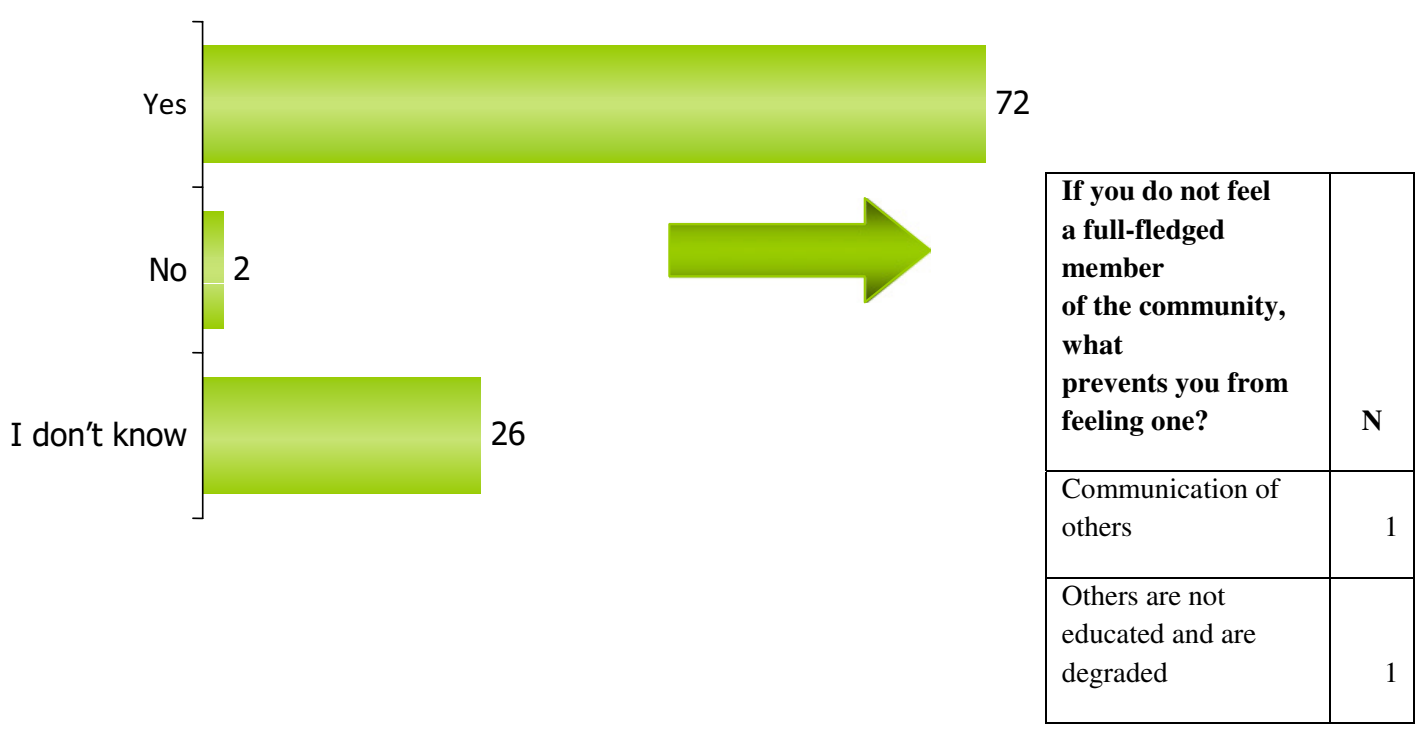

Figure 4. Assigning oneself to the community of the nursing home (percentage).

communicate with others, were statistically significantly unsure if they were able to assign themselves to the community. It can be concluded that individual's identification with the community of the social care home to big extent depends on the intensity of communication. The absolute minority (2\%) of elderly people mentioned that they did not feel members of the community (see: Fig. 4). These were the respondents, who did not communicate with other residents. They pointed out that this is determined by their dissatisfaction over communication with others or by the insufficient erudition of others. Communication with other residents is likely to be unpleasant for these respondents.

It is important to note that the respondents, who stated that they do not maintain close relations with others, also mentioned that they are not visited by anybody, they do not participate in any events held in the community or in any other activity, are very lonely, do not maintain any social links and feel isolated. They state that they are unhappy. The sense of identification with the community depends not only on communication with other members but also on the activity in the life of this community. Therefore, the research aimed to find out how many residents participate in amateur art activities of the social care 
Int. Conf. SOCIETY. HEALTH. WELFARE.

\section{Do you participate in cultural or sport activities of the community (amateur art activities, concerts, exhibitions, celebrate personal occasions, play board games, physically exercise)?}

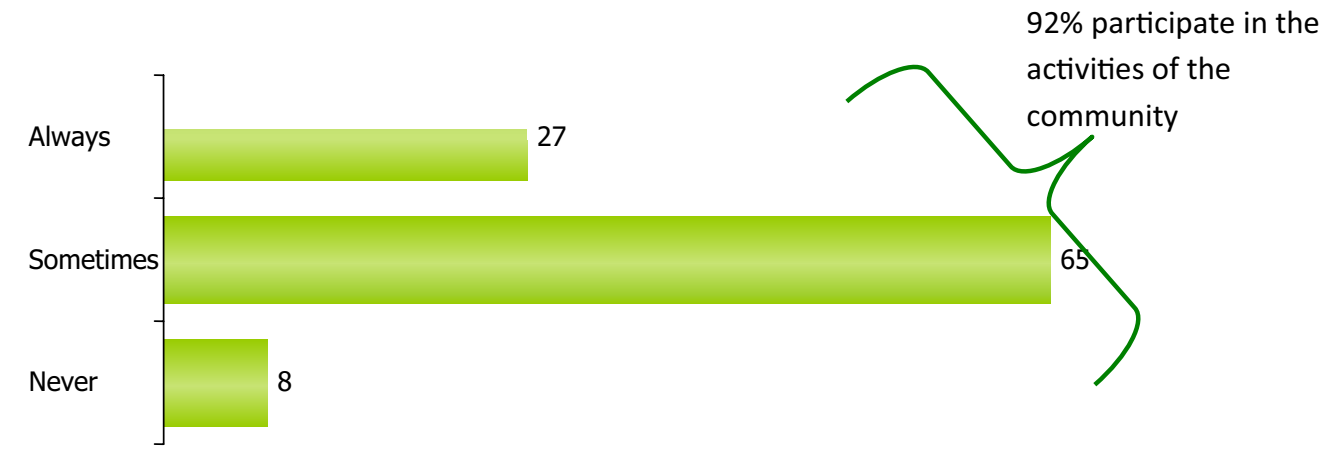

Figure 5. Participation in cultural and sport activities in the social care home (percentage).

home, concerts, exhibitions, celebrate personal occasions, play board games or physically exercise. One third of the respondents $(27 \%)$ are active members of the community, that is, they always participate in the organised activities. About $65 \%$ of the respondents are more passive members and $8 \%$ of them never involve in activities (see: Fig. 5). Thus, the absolute majority (92\%) participate in the activities organised in the social care home more frequently or seldom; however, not all the participants in the activities assign themselves to the members of the community.

Thus, it can be concluded that $14 \%$ of the residents of Utena social care home do not maintain relations with their relatives, family, neighbours and friends and only the absolute minority ( $2 \%$ ) of them do not communicate with other respondents, they do not feel members of the community and nobody visit them. Two thirds of the respondents cultivate close relations with other residents and are sure that they are members of the community. The majority of the respondents (92\%) take part in various events. During adaptation period the residents expect emotional and psychological assistance. Thus, social workers, working not only in the social care home but also in the eldership, and especially the ones who work as organisers of social work, should involve senior individuals into the community life (e.g., amateur art activities), they should organise exhibitions of works created by seniors, residents should celebrate anniversaries and other festivals. Such activities would contribute to social ecology, that is, to harmony of the relations of the society and individuals with the living environment and, thus, would facilitate maintenance of undisturbed and natural balance between senior individuals and their living conditions. It is recommended to send social workers to courses of psychology where they would be taught to provide efficient emotional, psychological assistance to senior individuals.

It is wery important, that The European Year of Voluntary Activities focused on the enhancement of the capacities of organisation to organise voluntary activities. The following projects were implemented: "Involvement of Elderly People in Voluntary Activities of the Provision of Social Services", "Development of Voluntary Activities in Community Organisations" and "Organisation of Training Courses for Organisations Engaged in Youth Voluntary Activities". The projects were successfully implemented in more than fifteen Lithuanian cities and attracted a large number of participants. The projects involved more than 800 participants from public institutions, budgetary institutions, associations, communities, libraries as well as elderly individuals. Seeking to make voluntary activities more popular and promote the involvement of a larger number of people, the competition of Capitals of Voluntary Activities was organised. Alytus, Biržai, Kèdainiai, Palanga and Šiauliai were awarded the title of a Capital of Voluntary Activities. This competition significantly contributed to the promotion of volunteering initiatives in regions and the formation of volunteering traditions. In the aforesaid 


\section{SHS Web of Conferences}

capitals, activities were carried out almost every day of a month; the competition rallied entrepreneurs, municipalities, local NGOs and residents. Thousands of peopleare estimated to have been involved in activities throughout all capitals; several hundreds of events, games, campaigns and projects were organised.

Another successful project which promoted volunteering was a cycle of TV programmes entitled "Office of Volunteers". Volunteers consulted with professionals and sought self-realisation, meaningful occupation, acquisition of relevant competences and new skills, also demonstrated that voluntary activities had to be carried out in a professional manner. Most TV programmes showed good practices of voluntary activities which were carried out in Lithuania yet known only to a small group of people.

The European Year of Voluntary Activities was successful in Lithuania, because state institutions, non-governmental organisations, the business sector and individuals developed many meaningful initiatives targeted at the promotion of volunteering in our country. A lot of ypoung people were voluntaring in Cocial care centres and do various activities by elderly people.

\section{Conclusions}

The research revealed that:

- The bigger proportion of the residents of the social care home still maintain relations with the world outside the social care home, the majority of them participate in the activity of the community and communicate with other residents of the institution;

- The assistance of social workers is of particular importance to individuals, who are not visited by anybody, who do not involve in the life of the social care home community and do not communicate with others. Though the proportion of such residents is not big, social workers are advised to pay particular attention to such individuals as well as to provide them with emotional and psychological assistance while communicating and integrating into the community.

- volunteering is good self-realisation for young people and voluntary activities for elderyly peoples and social care home residents as a precondition for coping with loneliness.

\section{References}

[1] Allport, Gordon Willard. Tapsmas: svarstymai apie asmenybės psichologiją. Vilnius, 1998.

[2] Birren J.E., Encyclopaedia of Gerontology: Age, Ageing and the Aged, vol. 1-2. San Diego, 1996.

[3] Ferry, Martin; Baker, Richard. Regioninès strategijos ir demografinis senejjimas. Pagyvenusiụ žmonių veiklos galimybiụ įvertinimo vadovas. Anglija: Age Concern, 2006. [accessed September 9, 2011]. Available at: www.openpdf.com/ebook/demografinis-pdf.html.

[4] Gudžinskienė V., Mačiuikienė D. Senyvo amžiaus asmenụ, gyvenančiụ socialinės globos namuose, socialiniụ darbuotojụ teikiamos pagalbos vertinimas. Socialinis ugdymas: Socialinè ekologija: mokslo darbai, 2011, Nr. 15 (26), p. 41-51. SocINDEX with Full Text, EBSCO Publishing http://www.epnet.com.

[5] Jonson, Louise C. Socialinio darbo praktika. Bendrasis požiūris. Vilnius: Specialiosios psichologijos laboratorija, 2001.

[6] Kart, Cary S. The Realities of Aging: An Introduction to Gerontology, 5th ed. Boston, 1997.

[7] Koskinen, Simo; Naujanienè, Rasa; Večkienè, Nijolè. Socialinė gerontologija: ištakos ir perspektyvos. Kaunas: Vytauto Didžiojo universitetas Socialinio darbo institutas, 2004.

[8] The Order of the Minister of Social Security and Labour of February 20, 2007 No.A1-46 "On Approval of Descriptor of Norms of Social Care" (Žin., 2007, No. 24-931).

$$
\text { 00011-p.6 }
$$


Int. Conf. SOCIETY. HEALTH. WELFARE.

[9] Pivorienè, Jolanta. Integracijos modeliai: nuo medicininès reabilitacijos ir finansinès kompensacijos prie visuminio požiūrio i negalią. Socialiniai neigalumo aspektai: žmogui reikia žmogaus. Kaunas: Vytauto Didžiojo universitetas, 2003.

[10] Pivorienè, Jolanta. Šeima, giminaičiai ir draugai. From: Socialinè gerontologija: ištakos ir perspektyvos. Kaunas: Vytauto Didžiojo universitetas Socialinio darbo institutas, 2004.

[11] Pivorienè, Jolanta. Pagyvenusių ir senų žmonių vaidmenų kaita šeimoje. Socialinis darbas. Vilnius: Mykolo Romerio universiteto leidykla, 2008, No.7(1), p. 41-45.

[12] Staniulevičienè, Dalia. Veikla ir gyvenimo būdas. From: Socialinè gerontologija: ištakos ir perspektyvos. Kaunas: Vytauto Didžiojo universitetas Socialinio darbo institutas, 2004.

[13] Večkienė, Nijolė; Večkys, Vidimantas; Vidugirytė - Hartblay, Miglè. Senèjimas bendruomenėje. From: Socialinė gerontologija: ištakos ir perspektyvos. Kaunas: Vytauto Didžiojo universitetas Socialinio darbo institutas, 2004. 